\title{
Krystian Barzykowski*
}

\author{
PERSPEKTYWA CZASOWA \\ A MYŚLENIE O PRZYSZŁOŚCI I PRZESZŁOŚCI \\ W KONTEKŚCIE TEORII POZIOMÓW REPREZENTACJI \\ (CONSTRUAL LEVEL THEORY)
}

\begin{abstract}
Przedmiotem artykułu jest teoria poziomów reprezentacji (Liberman i Trope 1998; Trope i Liberman 2003), zgodnie z którą przyjmowana perspektywa czasowa (bliskiej lub odległej przyszłości) sama w sobie kształtuje sposób, w jaki wydarzenia są reprezentowane. Wraz ze wzrostem dystansu temporalnego rośnie tendencja do przedstawiania wydarzeń w kategoriach abstrakcyjnych. Niewielki dystans temporalny prowadzi do reprezentowania wydarzeń w kategoriach konkretnych i szczegółowych. W artykule omówione zostały znaczenie problematyki efektu przyjmowanej perspektywy czasowej oraz jej implikacje teoretyczne i empiryczne dla myślenia o przyszłości i przeszłości. Zaproponowano również kierunki dalszych badań.
\end{abstract}

Słowa kluczowe: teoria poziomów reprezentacji, pamięć epizodyczna, myślenie o przyszłości, perspektywa temporalna/czasowa, poznawcze podróże w czasie

\section{WPROWADZENIE}

Trudno nie zgodzić się z twierdzeniem, iż czas jest tłem wszelkich naszych poczynań (Friedman 1993: 44, 60-62; Frideman 2004: 591, 600-601; Skowronski 2007: 4-7). Choć fizycznie znajdujemy się zawsze w określonym czasie i miejscu, to niejaką trudność sprawiać nam może kontemplacja jedynie „tu i teraz”. Zdaje się, że przebywanie myślami tylko w teraźniejszości jest niemożliwe (Klinger 1994: 97), bo czym jest „dzisiaj” pozbawione perspektywy dnia wczorajszego i jutrzejszego. Co więcej, przeszłość i przyszłość istnieją dzięki teraźniejszości, która z kolei rozwija się z przeszłości w kierunku przyszłości (związki te przybierać mogą jednak dowolną konfigurację (zob. Lens i Moreas 1994: 23). W związku z tym wspominamy „lata młodości”, znajomość z X, formułujemy prognozy/oczekiwania względem zbliżającego się tygodnia, roku, myślimy o przyszłych wakacjach czy też zmianie pracy. Wykraczając poza czas obiektywny i fizycznie nas określający, za każdym razem do końca nie zdając sobie z tego sprawy, posługujemy się innym dystansem/wymiarem temporalnym. Stanowi on podstawowe tło naszych rozważań (Friedman 2003: 60-62;

* Uniwersytet Jagielloński, krystian.barzykowski@onet.pl 
Friedman 2004: 603-604; Friedman 2005: 146, 148-149, 157; Savolainen 2006: 110; Skowronski 2007: 4-7). Niezależnie od tego, czy myślimy o przyszłości czy przeszłości, zawsze jest ona ,jakaś” (bliska, odległa, dawna, niedawna). Dystans temporalny pełni więc rolę kontekstu dla formułowanych wspomnień lub prognoz, tym samym wpływać może na ich formę i treść. Czasami staramy się przypomnieć sobie zdarzenie, które miało miejsce w określonym czasie w przeszłości (np. co robiłem / gdzie pracowałem cztery lata temu), innym razem natomiast próbujemy określić, kiedy zdarzenie miało miejsce (np. ile lat temu skończyłem studia, jak długo jesteśmy już małżeństwem). Uzasadnione zdaje się więc pytanie, czy (i jak) przyjmowana perspektywa czasowa kształtuje sposób reprezentowania zdarzeń w przyszłości (przewidywanych celów, planów) lub przeszłości. Pytanie jest typowe w kontekście psychologii temporalności, która za centrum swojego zainteresowania badawczego uznaje „rolę czasu w wewnętrznej strukturze zachowania” oraz poziomy i mechanizmy doświadczania czasu (Bajcar 2003: 82-95; Nosal 2006: 9-26; Nosal 2007: 111-130). Z jednej więc strony pojawia się pytanie, jak odbieramy (interpretujemy, przeżywamy) czas. Z drugiej natomiast, jak przyjmowany dystans temporalny wpływa na naszą wizję przyszłości lub przeszłości.

W ostatnich latach obserwuje się rosnącą liczbę badań psychologicznych nad wpływem przyjmowanej perspektywy czasowej na formułowane względem przyszłości cele, plany i prognozy (zob. Alexander, Lynch i Wang 2008; Liberman i Trope 1998; Liberman, Trope i Wakslak 2007; Nussbaum, Trope i Liberman 2003; Trope i Liberman 2000; Trope i Liberman 2003; Trope, Liberman i Wakslak 2007). Wyniki zdają się wskazywać (Trope i Liberman 2000; Trope i Liberman 2003), iż w zależności od czasu, który pozostał do realizacji hipotetycznego planu (zamiaru lub wystąpienia oczekiwanego zdarzenia), badani w systematyczny i określony sposób zmieniają swoje nastawienie względem nich (np. ocenę atrakcyjności). Innymi słowy, w zależności od tego, czy myślimy o zmianie pracy, która ma mieć miejsce w przyszłym tygodniu lub przyszłym roku, różne aspekty rozważanej zmiany są dla nas ważne (np. myślimy bardziej konkretnie o bliskiej przyszłości niż odległej). Zgodnie z zaproponowaną przez Liberman i Trope'a (Liberman i Trope 1998: 5-18; Trope i Liberman 2003: 403-421) teorią poziomów reprezentacji ${ }^{1}$ (Construal Level Theory) wraz ze wzrostem dystansu temporalnego (między „tu i teraz” a np. czasem wystąpienia oczekiwanego zdarzenia w przyszłości) rośnie tendencja osób badanych do myślenia w coraz bardziej ogólnych i abstrakcyjnych kategoriach. Wynika z tego, że im dalej „wybiegamy myślami w przyszłość”, tym mniej skłonni jesteśmy do myślenia o niej konkretnie i szczegółowo². Choć może wydawać się to oczywiste i naturalne (bo i dlaczego mielibyśmy myśleć o szczegółach wakacyjnego wyjazdu, który czeka

\footnotetext{
W niniejszym artykule zdecydowano się konsekwentnie thumaczyć Construal Level Theory jako teorię poziomów reprezentacji, a więc nieco odmiennie niż jest to stosowane w piśmiennictwie polskim, w którym spotkać można tłumaczenie: teoria poziomów interpretacji (np. Kulesza 2008: 203). Decyzję taką uzasadnia fakt, iż zgodnie z omawianą teorią perspektywa czasowa warunkuje bezpośrednio sposób, w jaki wydarzenie jest poznawczo przedstawiane (tj. odzwierciedlane, np. mniej lub bardziej szczegółowo, abstrakcyjnie). Co więcej, wydaje się, iż jednym z podstawowych atrybutów systemu poznawczego jest właśnie jego zdolność do poznawczego odzwierciedlania rzeczywistości (zob. Żegleń 2010: 166; Żegleń 2005: 37-57). Wydaje się to zgodne z założeniami teorii.

2 Teoria poziomów reprezentacji szerzej zostanie przedstawiona i omówiona w dalszej części artykułu.
} 
nas dopiero za dwa lata), to głębsze zastanowienie i analiza wyników dostarczają bardziej interesujących przykładów konsekwencji tego typu tendencji. Teoria przewiduje, między innymi, zmianę subiektywnej oceny rozważanego wyboru w zależności od tego, czy argumenty za lub przeciw niemu mają charakter ogólny lub konkretny. Skoro wraz ze wzrostem dystansu temporalnego myślimy w kategoriach bardziej ogólnych/abstrakcyjnych, to nasza ocena znajduje się pod coraz większym wpływem „danych” odpowiadających poziomowi abstrakcyjnemu niż konkretnemu. Innymi słowy, konkrety zdają się kształtować nasze decyzje odnoszące się do bliskiej przyszłości, tracąc na sile wraz z rosnącym dystansem temporalnym. Badani (Liberman i Trope 1998: 12) postawieni przed wyborem uczestnictwa w kursie interesującym, ale trudnym (A) lub łatwym, ale nieciekawym (B) byli w większym stopniu skłonni wybrać pierwszy (w porównaniu z drugim), gdy towarzyszyła im odległa perspektywa jego realizacji (tj. dopiero za dziewięć tygodni). Wyniki uległy odwróceniu, gdy kurs miał być realizowany już za tydzień ( $\mathrm{tj}$. bliska perspektywa czasowa). Wtedy też badani chętniej wybierali kurs mało ich interesujący, ale łatwy w realizacji. Potencjalne trudności zdają się więc mieć znaczenie przede wszystkim w odniesieniu do bliskiej nam przyszłości. Warto w tym miejscu podkreślić, iż efekt ten uzyskano, manipulując tylko perspektywą czasową (za tydzień vs. za dziewięć tygodni). Mając więc te same informacje, badani diametralnie różnili się oceną zbliżających się wydarzeń, w zależności od przyjętego przez nich tła temporalnego. Wyniki te stanowić mogą potwierdzenie założeń zaproponowanej przez Liberman i Trope’a teorii (Liberman i Trope 1998: 5-18; Trope i Liberman 2003: 403-421), której znaczenie ma wymiar zarówno teoretyczny (poznawcze mechanizmy oceny, wyboru, podejmowania decyzji), jak i praktyczny (perswazja, wpływ społeczny).

W kontekście omawianej teorii dziwić może jednak fakt, iż pomimo rosnącej liczby badań nad wpływem przyjmowanej perspektywy czasowej na myślenie o przyszłości, wpływ dystansu temporalnego na formę reprezentacji przeszłości pozostaje nieznany. Wydaje się, że badania umożliwiające określenie zakresu tego wpływu przyczynić się mogą nie tylko do pogłębienia wiedzy, ale także do rozpoczęcia dyskusji nad mało znanym dotąd poznawczym mechanizmem konstruowania przeszłości (różnych jej odmian niezależnie od tego, jak bliskie są rzeczywistości). Prawdopodobnie to, w jaki sposób mówimy o przeszłości (i jakie treści wspomnień przywołujemy) jest procesem limitowanym zarówno dostępnością „danych” (także ich jakością, rodzajem), jak również mechanizmami, które od treści wspomnień są niezależne. Być może bliższa i dalsza przeszłość są inaczej oceniane (wedle różnych kryteriów) bez względu na to, co stanowi jej przedmiot. Wraz z upływem czasu więc zdajemy się nie tylko o czymś zapominać (np. o powodach podjęcia decyzji), ale także zmienia się nasz swoisty „punkt widzenia” przeszłych wydarzeń. Z tego względu odległa przeszłość wydaje się bardziej spójna, uporządkowana i mniej różnorodna, w porównaniu z mniej oddaloną w czasie. Zadowolenie z czasem ustępować może więc miejsca niezadowoleniu (lub na odwrót). Praktycznie może mieć to znaczenie w szczególności w przypadku terapii czy pomocy psychologicznej (np. radzenie sobie z pamięcią zdarzenia traumatycznego przez podkreślanie niegroźnych, drugorzędnych aspektów zdarzenia itd.).

W dalszej części artykułu najpierw zaprezentowana zostanie teoria zaproponowana przez Liberman i Trope'a (Liberman i Trope 1998: 6-7) wraz z omówieniem wyników badań prowadzonych w tym nurcie teoretycznym. Następnie przedstawiona zostanie nowa 
perspektywa, która stanowi próbę zastosowania omówionej teorii do analiz teoretycznych i badań empirycznych dotyczących pamięci osobistej przeszłości.

\section{TEORIA POZIOMÓW REPREZENTACJI}

Podstawowym założeniem teorii poziomów reprezentacji (Construal Level Theory, w skrócie CLT, zob. Liberman i Trope 1998: 6-7; Trope i Liberman 2003: 405-406) jest to, iż dystans temporalny bezpośrednio wpływa i warunkuje poziom poznawczej reprezentacji „problemu”3. Im bardziej odległa przyszłość, tym silniejsza (ważniejsza) jest reprezentacja wyższego poziomu (i na odwrót). Ta sama informacja w tym samym czasie może być więc diametralnie różnie odbierana, interpretowana i przetwarzana w zależności od przyjętej perspektywy czasu. Innymi słowy, konstruujemy różne reprezentacje tego samego „problemu” w zależności od tego, czy rozpatrywany jest on z perspektywy, na przykład, przyszłego tygodnia lub przyszłego miesiąca.

Autorzy (Liberman i Trope 1998: 5-18; Trope i Liberman 2003: 403-421) wyróżniają dwa poziomy reprezentacji ,problemu” (zestawienie oraz porównanie najważniejszych cech każdego z nich zostało schematycznie przedstawione na rycinie 1).

Poziom wysoki (zamiennie stosowany z określeniem poziom I, High-Level) jest właściwy odległej perspektywie temporalnej. Pozbawiony informacji szczegółowych (konkretnych), odnoszących się do kontekstu, zawiera najważniejsze informacje (kluczowe oraz definicyjne, tj. odwołuje się do istoty „,problemu”). Z tego względu każda zmiana elementów składowych reprezentacji tego poziomu (nawet niewielka) prowadzić może do zmiany całego jej znaczenia (np. bycie utalentowanym zamiast bycie muzykalnym itd). Reprezentacja poziomu pierwszego ma charakter abstrakcyjny i uogólniony, czego przejawem jest wysoka organizacja wewnętrzna „problemu” stanowiącego spójną i homogeniczną klasę elementów go tworzących (np. dobry dzień za rok opisywany jest jako zbiór w dużej mierze podobnych do siebie zdarzeń).

Bliska przyszłość opisywana jest za pomocą niskiego poziomu reprezentacji (poziom II, Low-Level). Zawiera informacje konkretne, o drugorzędnym (a więc mniej istotnym, incydentalnym i epizodycznym) charakterze - zmiana poszczególnych elementów tej reprezentacji nie prowadzi do istotnej zmiany całego jej znaczenia. Informacje tego poziomu opisywane są przez kontekst, w granicach którego się realizują (w przeciwieństwie do uogólnień i abstrakcji poziomu wysokiego). „Problem” bliskiej przyszłości charakteryzuje się dużą liczbą elementów o niskim poziomie organizacji i uporządkowania.

Ważną konsekwencją założeń teorii CLT jest oczekiwana zmiana wagi przypisywanej poszczególnym aspektom ,,problemu”, w zależności od przyjmowanego dystansu temporalnego. Znaczenie charakterystyk wysokiego poziomu rośnie wraz ze wzrostem odległości umiejscowienia danego wydarzenia na kontinuum czasu od teraźniejszości, podczas gdy znaczenie charakterystyk niskiego - maleje. W związku z tym jeżeli znaczenie poziomu I jest spostrzegane jako pozytywne (wartościowe/atrakcyjne/pożądane w porównaniu

3 W dalszej części stosować będę termin ,problem” (w cudzysłowie) jako określenie przedmiotu rozważania związanego z hipotetyczną przyszłością lub przeszłością (np. planowany wyjazd, decyzja do podjęcia itd.). 
z poziomem II), to siła jego wpływu na podejmowaną decyzję powinna rosnąć wraz ze wzrostem dystansu temporalnego i przeciwnie, powinna maleć, gdy atrakcyjność powiązana jest z poziomem niższym.

Reprezentacja czynności/zdarzeń. Na podstawie wcześniejszych rozważań można oczekiwać opisywania czynności w sposób bardziej lub mniej abstrakcyjny w zależności od przyjętej perspektywy czasowej. Zastanawia jednak to, co tak naprawdę znaczy definiowanie czynności bardziej/mniej abstrakcyjnie. Jak wynika z badań Liberman i Trope'a (Liberman i Trope 1998: 8), czynności, które mają być wykonywane w odległej przyszłości (za rok) stanowiły element składowy większej całości (planu), która za pomocą tych czynności była definiowana i opisywana (description by activity). „Jutrzejsza aktywność” (bliska przyszłość) definiowana była natomiast opisem jej wykonania (activity by description). W pierwszym wypadku czynność ma więc charakter podrzędny (jest częścią większego planu), w drugim jest nadrzędna względem opisu ${ }^{4}$.

Interesującą konsekwencją efektu poziomu reprezentacji jest tendencja osób badanych do stosowania mniejszej liczby szerokich kategorii w odniesieniu do obiektów odległej przyszłości (w porównaniu z dużą liczbą wąskich, wzajemnie wyłączających się kategorii bliskiej przyszłości, zob. Liberman, Sagristano i Trope 2002: 525-527). Badani, mając listę trzydziestu ośmiu obiektów związanych z hipotetycznym wyjazdem pod namiot, tworzyli więcej grup, gdy wyjazd miał mieć miejsce w zbliżający się weekend. W kolejnych badaniach okazało się także (Liberman, Sagristano i Trope 2002: 525-527), że zdarzenia odległej przyszłości opisywane są jako bardziej schematyczne i prototypowe ${ }^{5}$. Schematyczność przejawiała się przede wszystkim mniejszą różnorodnością wewnątrzkategorialną (intra-category heterogeneity) oraz większą międzykategorialną. Oznacza to, że doświadczenia w obrębie odległego dnia (dobrego lub złego) były względem siebie bardziej podobne i spójne niż w obrębie dnia bliższego teraźniejszości. W perspektywie jutra pojawia się większe zróżnicowanie możliwych doświadczeń (pozytywnych, neutralnych i negatywnych). Co więcej, dobry (lub zły) dzień za rok okazał się być lepszy (gorszy), w porównaniu z dobrym (gorszym) dniem jutrzejszym. Spójność wewnętrzna i różnorodność zewnątrzkategorialna może być interpretowana jako wynik tendencji badanych do tworzenia różnej liczby kategorii (klasy obiektów), różniących się zakresem.

Zmiany w zakresie preferencji. W jaki sposób dystans temporalny wpływa na atrakcyjność opcji wyboru? Na podstawie teorii CLT można oczekiwać podobnych, do wcześniej opisanych, zależności. To, czy daną opcję uznamy za atrakcyjną (tj. pożądaną) zależeć powinno

\footnotetext{
4 Niech za przykład posłuży aktywność pisania pracy magisterskiej. Teoria przewiduje, iż trzy lata temu czynność ta byłaby definiowana przeze mnie, jako część większego planu „kończenie studiów” (np. uzyskanie wykształcenia wyższego, tytułu magistra itd.). Z perspektywy dnia wczorajszego prawdopodobny opis skupiałby się na kolejnych etapach pisania pracy magisterskiej (np. próba przedstawienia podłoża teoretycznego w sposób jasny, zrozumiały i syntetyczny). Również wyniki badania Liberman i Trope'a (badanie 1, część 2, Liberman i Trope 1998: 8-9) wskazują, iż dystans temporalny w sytuacji wymuszonego wyboru zdaje się kształtować odpowiedzi badanych zgodnie z teorią CLT.

5 Badani (Liberman, Sagristano i Trope 2002: 526) proszeni byli o opisanie, jak według nich wygląda (pod względem zdarzeń, które mogą nastąpić) dobry lub zły dzień (jutro vs. za rok). Zdarzenia oceniane były również pod względem: prawdopodobieństwa ich zaistnienia, subiektywnej wartości (neutralne, negatywne, pozytywne).
} 
od interakcji dwóch czynników: (a) perspektywy czasu oraz (b) spostrzeganej wartości opcji (reprezentowanej na poziomie sprzężonym z perspektywą czasową). W tabeli 1 przedstawiono dwie hipotetyczne opcje wyboru (których aspekty poziomu I i II są przeciwstawne) i oczekiwane różnice $\mathrm{w}$ ocenie ich atrakcyjności (w porównaniu z: tą samą opcją przy zmianie perspektywy czasu oraz opcją przeciwną w tej samej perspektywie). W odległej przyszłości wybór jest „,bliższy” preferencji (lub jej braku) aspektów wysokiego poziomu. Odwrotna sytuacja towarzyszy perspektywie niezbyt odległej przyszłości. Jak wynika z tabeli 1, atrakcyjność pierwszej opcji rośnie wraz ze wzrostem dystansu temporalnego (drugiej natomiast spada), prowadząc tym samym do zmiany preferowanego wyboru. Kwestia preferencji może być więc tylko kwestią czasu.

Tabela 1. Perspektywa czasu i spostrzegana wartość alternatyw do wyboru a ich preferencja

\begin{tabular}{|l|l|l|l|l|}
\cline { 2 - 5 } \multicolumn{1}{c|}{} & \multicolumn{2}{c|}{$\begin{array}{c}\text { Poziom reprezentacji } \\
\text { opcji }\end{array}$} & \multicolumn{1}{c|}{$\begin{array}{c}\text { Perspektywa czasu } \\
\text { a preferencja opcji wyboru }\end{array}$} \\
\cline { 2 - 5 } & \multicolumn{1}{c|}{ Wysoki } & \multicolumn{1}{c|}{ Niski } & \multicolumn{1}{c|}{ Bliska } & \multicolumn{1}{c|}{ Odległa } \\
\hline $\begin{array}{l}\text { Spostrzegana wartość opcji 1 } \\
\text { (zadanie ciekawe, ale trudne) }\end{array}$ & $\begin{array}{l}\text { Pożądana } \\
\text { (ciekawe) }\end{array}$ & $\begin{array}{l}\text { Niepożądana } \\
\text { (trudne) }\end{array}$ & $\begin{array}{l}\text { Niżej oceniana } \\
\text { alternatywa 1 }\end{array}$ & $\begin{array}{l}\text { Wyżej oce- } \\
\text { niana } \\
\text { alternatywa 1 }\end{array}$ \\
\hline $\begin{array}{l}\text { Spostrzegana wartość opcji 2 } \\
\text { (zadanie nieciekawe/łatwe) }\end{array}$ & $\begin{array}{l}\text { Niepożądana } \\
\text { (nieciekawe) }\end{array}$ & $\begin{array}{l}\text { Pożądana } \\
\text { (łatwe) }\end{array}$ & $\begin{array}{l}\text { Wyżej oce- } \\
\text { niana } \\
\text { alternatywa 2 }\end{array}$ & $\begin{array}{l}\text { Niżej oceniana } \\
\text { alternatywa 2 }\end{array}$ \\
\hline
\end{tabular}

Wyniki badania przeprowadzonego przez Trope'a i Liberman (badanie 4, Trope i Liberman 2000: 883) zdają się poprzednie rozważania potwierdzać. Osobom badanym prezentowano opisy dwóch eksperymentów (który miał się odbyć za kilka minut lub za kilka tygodni (4-6)). Należały one do jednej z kategorii: (a) ciekawego zadania głównego (eksperymentalnego ocena śmieszności kreskówek) i nieciekawego zadania pobocznego (,wypełniacza” czasu pomiędzy kolejnymi sesjami zadań głównych - porównywanie kolumn liczb), (b) kategorii będącej przeciwieństwem poprzedniej. Zgodnie z przewidywaniami uczestnicy istotnie wyżej oceniali interesującą pracę w perspektywie odległej niż bliskiej przyszłości. Zadanie przeciwne natomiast wraz ze wzrostem dystansu temporalnego oceniane było jako mniej atrakcyjne. Podobne rezultaty uzyskano niezależnie od tego, czy badanie dotyczyło spostrzeganej wartości czynności, nadrzędnego/podrzędnego aspektu hipotetycznej pracy czy głównej/drugorzędnej funkcji produktu.

Wyniki badań (Liberman i Trope 1998: 7-13) nad różnicami w preferencji czynności nastawionych na osiągnięcie celu również okazały się zgodne z oczekiwaniami teorii CLT. Poziomy konstrukcji różniły się pod względem akcentowania aspektu wykonalności (łatwość/ trudność realizacji celu, feasibility) lub atrakcyjności (interesujące/ nieinteresujące, desirability). Pierwszy (np. nakład czasu i pracy) odpowiada poziomowi II, drugi nadrzędnemu poziomowi I. 


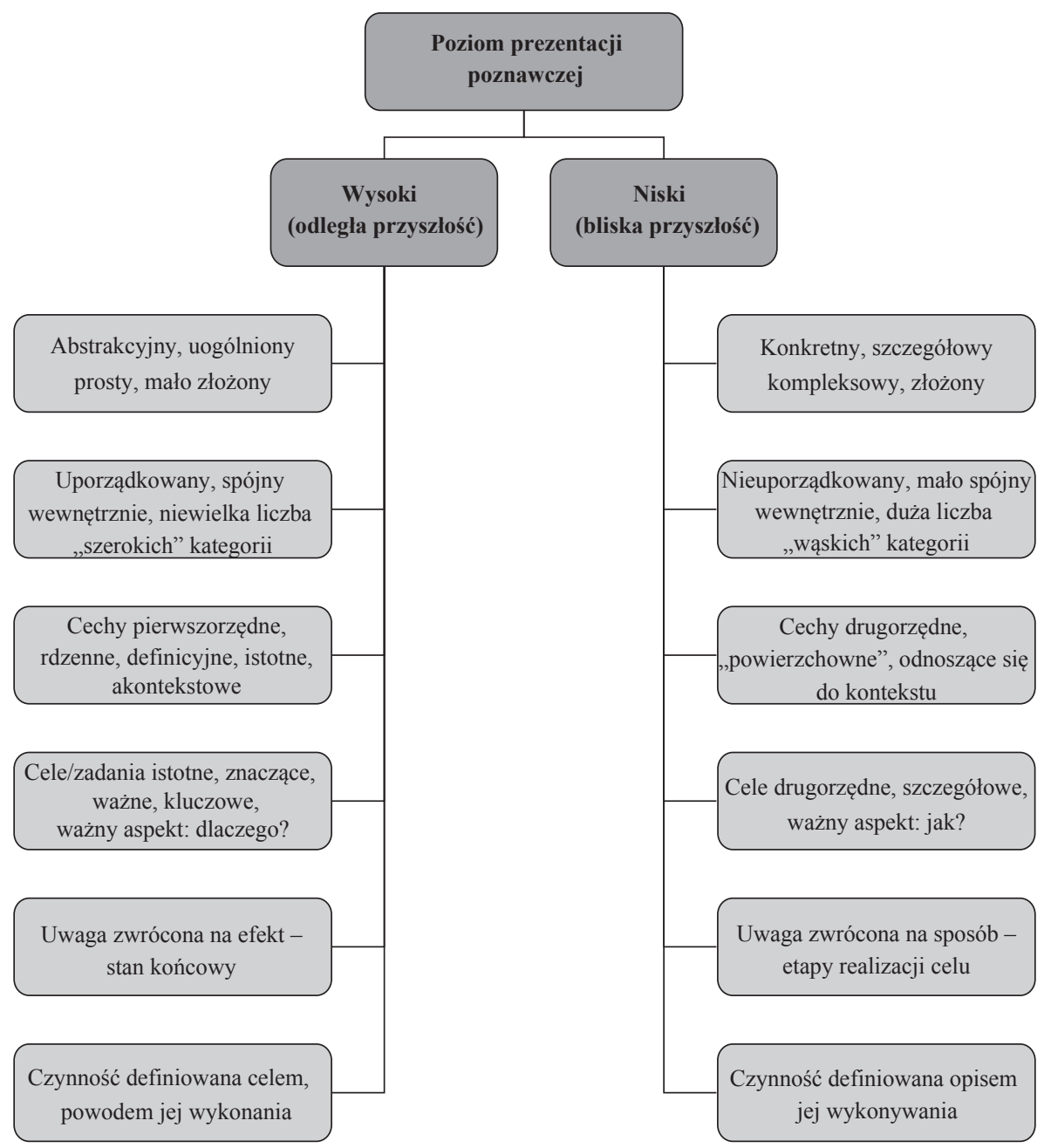

Rycina 1. Porównanie cech wysokiego i niskiego poziomu reprezentacji. Opracowanie własne na podstawie Liberman i Trope (1998), Trope i Liberman (2003)

Nietrudno przewidzieć, że czas powinien uwydatnić znaczenie drugiego w porównaniu z pierwszym (por. tabela 1). Szczególnie warte opisania zdaje się badanie Liberman i Trope'a (badanie 4, Liberman i Trope 1998: 883), które jest przykładem wpływu perspektywy czasu w realistycznej sytuacji na wybór. Studentów uniwersytetu w Tel-Avivie poproszono o ocenę, jak bardzo chcą realizować każde z proponowanych zadań w bliskiej lub odległej przyszłości (był to warunek zaliczenia kursu polegający na czytaniu rozdziału w języku angielskim lub hebrajskim i odpowiadaniu na pytania testowe). Ocenie podlegały cztery różne zadania, stanowiące wszystkie możliwe kombinacje aspektów: wykonalności zadania (trudne vs. łatwe) 
i jego atrakcyjności (interesujące vs. nieinteresujące). Uczestnicy kursu oceniali, jak bardzo chcą czytać rozdział: w języku angielskim (zadanie trudne) lub języku ojczystym (hebrajski, łatwe zadanie) na ciekawy lub nieciekawy temat. Jedne z zadań miały być realizowane w bliskiej przyszłości (tego samego dnia), inne natomiast dziewięć tygodni później. Tabela 1 przedstawia przewidywany charakter zmiany w zakresie preferowanych opcji wyboru. Zgodnie z oczekiwaniami badani istotnie wyżej oceniali zadanie ciekawe i trudne (odległe w czasie), w porównaniu z tym samym zadaniem, ale w bliskiej przyszłości oraz nieciekawym $\mathrm{i}$ trudnym w odległej. Oceny atrakcyjności zadania nieciekawego i łatwego (nieodległe w czasie) były wyższe w porównaniu z tym samym zadaniem w odległej przyszłości i przeciwnym (ciekawym i trudnym) w bliskiej. Studenci rezygnowali więc z łatwości na rzecz zainteresowania i odwrotnie, w zależności od tego, czy kurs miał być realizowany w bliskiej czy też w dalszej przyszłości.

Nie należy zapominać jednak, iż proces dokonywania wyboru nie jest uzależniony tylko i wyłącznie od jego tła temporalnego. Co więcej, rzadko dokonujemy wyboru pomiędzy dwoma tylko opcjami. Wybory różnią się ważnością, a więc również zaangażowaniem i poświęcaną im uwagą. Wyniki badań jednak zdają się sugerować, że perspektywa czasowa (sama w sobie) jest istotnym czynnikiem, którego wpływ na konstrukcję i opracowywanie hipotetycznego ,problemu” nie powinien być lekceważony. Nie wiadomo jednak, czy (i w jaki sposób) kształtuje ona sposób, w jaki pamiętamy osobistą przeszłość.

\section{TEORIA POZIOMÓW REPREZENTACJI A PAMIĘĆ OSOBISTEJ PRZESZŁOŚCI}

Pamięć zdefiniowana może być jako zdolność (przynależna różnym osobom w różnym stopniu) lub proces rozciągnięty w czasie, którego poszczególne etapy u wszystkich osób przebiegają w podobny sposób (Falkowski, Maruszewski i Nęcka 2008). W pierwszym przypadku traktowana jest więc statycznie jak magazyn informacji, swoisty zbiór, który charakteryzuje się określoną strukturą oraz rodzajem przechowywanej treści. Prowadzi to do pytania o zawartość pamięci, jej organizację oraz wzajemne powiązania między tworzącymi ją elementami (Maruszewski 2005: 54; Nęcka, Orzechowski i Szymura 2007). Drugie ujęcie, traktując pamięć procesualnie, skupia się przede wszystkim na sposobie jej funkcjonowania i przebiegu poszczególnych etapów procesu pamięciowego (tj. kodowania, przechowywania, przypominania), którym wspomnienia podlegają. Pamięć traktowana dynamicznie opisywana jest jako wyspecjalizowany mechanizm, dzięki któremu możliwe jest gromadzenie przez jednostkę doświadczenia (Maruszewski 2005: 18). Ten sposób jej rozumienia prowadzi do pytania o mechanizmy i reguły jej funkcjonowania. Choć obydwa sposoby definiowania różnią się podejściem do pamięci, to, jak można zauważyć, dotyczą tego samego obiektu. Opisując różne jego aspekty, wzajemnie się więc uzupełniają.

Podobnie jak pamięć w ogóle również pamięć zdarzeń z przeszłości rozumiana może być szeroko lub wąsko (Łukaszewski 2003). Szerokie rozumienie dotyczy wszystkich zdarzeń, których jednostka była świadkiem niezależnie od tego, czy odnoszą się one stricte do samego podmiotu. Wąskie jej rozumienie odnosi się natomiast tylko do wydarzeń powiązanych 
z Ja, a więc pamięci autobiograficznej. Dookreślając, czym jest pamięć autobiograficzna, A. Baddeley (Baddeley 1992: 13-29) dokonał rozróżnienia na Ja doświadczające oraz Ja będące przedmiotem/treścią doświadczenia. Pierwsze z nich odpowiada ujęciu szerokiemu, które swym zakresem obejmuje wszystkie możliwe wspomnienia zdarzeń bezpośrednio doświadczonych przez podmiot. Jest ono jednak na tyle szerokie, że opisuje raczej pamięć epizodyczną niż odrębną od niej formę pamięci ${ }^{6}$. Drugi sposób rozumienia Ja według A. Baddeleya (Baddeley 1992: 13-29) jest specyficzny dla pamięci autobiograficznej i pozwala na jej wyodrębnienie jako przedmiotu osobnej problematyki badawczej pamięci (Niedźwieńska 2000). Zgodnie z nim dotyczy ona wspomnień przywołującego je podmiotu, których sam jest treścią (tj. ich bohaterem, aktorem, uczestnikiem zdarzenia). Innymi słowy jest ona związana z informacjami (zarówno semantycznymi, jak i epizodycznymi) o podmiocie. Tak jak pamięć epizodyczna dotyczy zdarzeń z przeszłości danej osoby (umieszczanych w czasie i przestrzeni, osobistych oraz nieosobistych), tak pamięć autobiograficzna odnosi się do zdarzeń z własnej przeszłości, zawierając elementy zarówno semantyczne, jak i epizodyczne. Elementy semantyczne dotyczą przede wszystkim faktów autobiograficznych (np. imię, nazwisko, data urodzenia), epizodyczne natomiast odnoszą się do zdarzeń osobistych (Maruszewski 2001; Maruszewski 2005: 20-21; Niedźwieńska 2004). Zdarzenia te zdają się częścią wspólną pamięci epizodycznej i autobiograficznej (Niedźwieńska 2004). Poza nimi jednak obydwie mają własny niesprowadzalny do drugiego zakres. Należy podkreślić, iż stosowanie podziału pamięci na różnorodne jej formy ma charakter przede wszystkim teoretyczny i porządkujący (Tulving 2002). Dzięki precyzyjniejszemu określeniu obszaru badań przyczyniać się to może do wzrostu trafności ekologicznej badań laboratoryjnych nad pamięcią (Niedźwieńska 2000). Pozwala również odpowiedzieć na pytanie, w jakim stopniu ich wyniki mogą być generalizowane i obejmować również sytuację „kontekstu dnia codziennego”.

Pamięć osobistej przeszłości jest wynikiem współdziałania procesów reprodukcji i konstrukcji, tak więc ma ona głównie charakter rekonstrukcyjny (Draaisma 2006; Loftus 1975: 560-572; Łukaszewski 2003; Maruszewski 2001; Maruszewski 2005: 90-106; Stanisławiak 2005: 243-259; Stawiska 2004: 81-91). Model strukturalnej organizacji zawartości pamięci autobiograficznej, przedstawiony przez Conwaya (Conway 1995: 67-93) oraz Conwaya i Pleydella-Pearce'a (Conway i Pleydell-Pearce 2000: 261-288), dobrze fakt ten akcentuje. Zgodnie z nim wspomnienia mają charakter chwilowej, przejściowej konstrukcji umysłowej

6 Endel Tulving (Endel Tulving 1972; Endel Tulving 1984) wprowadził podział pamięci długotrwałej na semantyczną i epizodyczną, wzbogacając go później dodatkowo o pamięć proceduralną (1985). Ta ostatnia uważana była przez niego za najbardziej podstawową formę pamięci (pojawiającą się w rozwoju ontogenetycznym najwcześniej). Za jej pośrednictwem zachodzi uczenie się skojarzeń między bodźcem a reakcją (Tulving 1985). Wyróżnione systemy różnią się między sobą i są względnie od siebie niezależne. System semantyczny to szeroko pojęta wiedza dotycząca faktów, idei, znaczeń zorganizowanych pojęciowo, mających uniwersalny charakter. Niezależnie od naszego doświadczenia (kontekstu, miejsca i czasu) nabywana może być w sposób pośredni (np. z książek). System epizodyczny dotyczy natomiast zdarzeń, epizodów ściśle określonych przez czas i miejsce (umiejscowionych w czasie i przestrzeni), zorganizowanych temporalnie zgodnie z ich czasowym występowaniem. Informacje pamięci epizodycznej nabywane są bezpośrednio przez własne doświadczenie. Dotyczą przede wszystkim osobistej historii i biografii. Zgodnie z tym pamięć osobistej przeszłości mieściłaby się w ramach systemu epizodycznego. 
tworzonej przez centralny system wykonawczy na podstawie „bazy danych” autobiograficznych. Autorzy dokonali rozróżnienia między wspomnieniami (rozumianymi jako konstrukcja) i zasobami zapisanego materiału (pewnej bazy informacji). Tym samym rozpatrywali zarówno aspekt dynamiczny, jak i statyczny pamięci. Głównym zadaniem systemu wykonawczego jest aktywizowanie informacji z bazy wiedzy autobiograficznej, przywoływanie planów zgodnych $\mathrm{z}$ aktualnie wykonywanym zadaniem i jednoczesne hamowanie zachowań (lub wzorów aktywizacji informacji z „bazy danych”), które mogłyby doprowadzić do jego przerwania. Treść wspomnienia zależy więc od celu jego przywołania, adresata (czy jest nam bliską czy obcą osobą), a także od aktualnej sytuacji, w której przebiega. W rekonstrukcyjnym charakterze pamięci tkwi więc przesłanka sugerująca, iż prawdopodobnie perspektywa czasowa wpływa na sposób, w jaki przeszłe treści są reprezentowane ${ }^{7}$. Warto w tym miejscu podkreślić, iż możliwy wpływ perspektywy czasowej na konstruowanie przeszłości nie musi ograniczać się tylko do pamięci osobistych zdarzeń, ale również może wiązać się z pamięcią epizodyczną czy też semantyczną (a więc z pamięcią w ogóle).

Perspektywy badawcze. Zasadniczym, w kontekście omówionej teorii, celem dalszych badań jest odpowiedź na pytanie, czy podobne efekty występują również w odniesieniu do przeszłości. Czy perspektywa bliskiej/odległej przeszłości wpływa na sposób myślenia i formułowania wniosków o przeżytych wydarzeniach? Czy wpływ ten również istnieje w odniesieniu do pamięci zdarzeń z przeszłości? Z jednej strony doświadczenie może wskazywać na odpowiedź twierdzącą (w co wierzą Trope i Liberman 2003: 417; z czasem zapominamy o trudnościach wyprawy w góry sprzed dwóch lat, natomiast dobrze pamiętamy poczucie satysfakcji, spełnienia po wejściu na szczyt). Z drugiej natomiast strony, z racji braku systematycznych badań, nie można jednoznacznie orzec, czy przyjmowana perspektywa temporalna (tj. odległej vs. bliskiej przeszłości) sama przez się wpływa na to, jak pamiętamy/oceniamy naszą przeszłość ${ }^{8}$. Y. Trope i N. Liberman (Trope i Liberman 2003: 417) zwracają uwagę, iż pewną przesłanką sugerującą istnienie analogicznego efektu w „myśleniu o przeszłości” mogą być wyniki badań między innymi M. Rossa (Rossa 1989: 341-357) czy też T.R. Mitchella i współpracowników (Mitchell, Thompson, Peterson i Cronk 1997: 421-448). Wskazują one, iż wspomnienia odległej przeszłości są rekonstruowane zgodnie z abstrakcyjnymi teoriami im odpowiadającymi (por. Ross 1989: 341-357), stając się z czasem bardziej schematyczne i pozbawione szczegółów (Mitchell, Thompson, Peterson i Cronk 1997). Interesujących wyników dostarczają również Semin i Smith (Semin i Smith 1999: 877-892), którzy zainteresowali

7 W tym sensie rycina 1 pokazuje w sposób kompletny i wyczerpujący, jakich różnic można byłoby się spodziewać w konstruowaniu dalszej i bliższej przeszłości, gdyby okazało się, że efekt wpływu perspektywy czasowej również w niej istnieje. Innymi słowy, na rycinie 1 przedstawiono komplet hipotetycznych założeń do możliwej weryfikacji w kolejnych badaniach oraz możliwy kierunek ich rozwoju.

8 Za odpowiedzią twierdzącą opowiedziałby się prawdopodobnie George Herbert Mead (Mead 1932: 12), dla którego „przeszłość (lub struktura przeszłości odpowiadająca) jest równie hipotetyczna jak przyszłość”. Przewrotność twierdzenia nabiera „mocy wykonawczej”, kiedy uświadomimy sobie, iż pamięć osobistej przeszłości nie jest prostym odzwierciedleniem rzeczywistości, a raczej jej interpretacją oraz rekonstrukcją uzależnioną od podmiotu ją postrzegającego (Stawiska 2004: 81-91; zob. także: Draaisma 2006; Loftus 1975: 560-572; Łukaszewski 2003; Maruszewski 2001; Maruszewski 2005; Stanisławiak 2005: 243-259). Wspomnienia mają więc charakter przejściowy i uzależnione są, w pewnej mierze, od kontekstu sytuacji, w której powstają (Conway 1995: 67-93; Conway i Pleydell-Pearce 2000: 261-288). 
się sposobem, w jaki zdarzenia z bliskiej i odległej przeszłości są przechowywane w pamięci i komunikowane językowo. Badani proszeni byli o przypomnienie sobie i opisanie istotnych zdarzeń z bliskiej lub odległej przeszłości (a więc dobrze przez nich pamiętanych i przez nich samych wybranych). Wspomnienia odleglejsze w czasie były opisywane w kategoriach bardziej abstrakcyjnych i uogólnionych. Wyniki kolejnych badań (Semin i Smith 1999: 877-892) pokazały, iż wskazówki konkretne (odczasownikowe) generują wspomnienia średnio o osiem/dziewięć miesięcy młodsze w porównaniu ze wskazówkami bardziej ogólnymi (np. odprzymiotnikowymi). Podobnych wyników nie zaobserwowali oni jednak w odniesieniu do przyszłości, co stanowi przesłankę, iż uzyskany efekt nie był spowodowany semantyczną lub leksykalną formą wskazówek ${ }^{9}$. Wyniki badań wspomnianych autorów zdają się również sugerować, iż poza oczywistym i mało intrygującym sposobem bezpośredniego „kodowania” czasu zdarzeń (przez określenia do niego nawiązujące, np. wczoraj, dwa lata temu, piątego sierpnia, lub struktury czasowe, szczególnie w języku angielskim) istnieje bardziej pośrednia (niejawna i utajona) forma jego opisu. Oczekiwać więc można, iż skoro odległe zdarzenia opisywane są abstrakcyjnie, to prośba przywołania wspomnień zdarzeń z odległej przeszłości powinna prowadzić do przypomnienia ich (tj. składników je tworzących) na określonym poziomie reprezentacji (niektóre wyniki badań zdają się to potwierdzać, zob. Davison i Feeney 2008: 385-403).

Podsumowując, można stwierdzić, że badani są bardziej skłonni do konstruowania wspomnień na wyższym poziomie abstrakcji i ogólności, gdy odnoszą się one raczej do odległej niż bliskiej przeszłości. Trudno jednak zgodzić się z wyjaśnieniem, tych i im podobnych rezultatów, wyłącznie w kategoriach teorii poziomów reprezentacji (Trope i Liberman również są tego świadomi). Powodem tej trudności jest przede wszystkim fakt utraty wraz z upływem czasu szczegółów dotyczących wspomnień oraz spadek ich dostępności. Z czasem zarówno ilość, jak i dostęp do ,żywych” danych (tj. konkretnych, szczegółowych) o charakterze percepcyjnym maleje (Burt i Kemp 2003: 317-325; Piolino, Desgranges, Benali i Eustache 2002: 239-257), prowadząc tym samym do zjawiska schematyzacji pamięci (Burt i Kemp 2003: 317-325). Być może z jednej strony wpływ czasu prowadzi do zubożenia liczby szczegółów w pamięci, z drugiej natomiast, proces ten może być wzmacniany tendencją osób badanych do opracowywania przeszłości na wyższym poziomie ogólności i mniejszym przywiązywaniem wagi do szczegółów (te ostatnie są pamiętane o tyle, o ile mają znaczenie dla podmiotu). $\mathrm{Z}$ tego względu pojawia się konieczność oddzielenia pamięciowych mechanizmów efektu dystansu temporalnego (np. zapominania, utraty informacji z czasem itd.) od jego źródeł pozapamięciowych. Próbą realizacji tej konieczności może być badanie wpływu przyjmowanej perspektywy czasowej na myślenie o hipotetycznej (a więc nieodnoszącej się do pamięci) przeszłości. Umożliwi to kontrolę procesów o charakterze pamięciowym (np. zapominania) oraz weryfikację założenia, iż przeszłość stanowi podobną do przyszłości ,przestrzeń” wpływu efektu dystansu temporalnego na rozważania, twierdzenia lub oceny do niej się odnoszące.

9 Rezultaty badania Semina i Smitha (Semin i Smith 1999: 877-892) wskazują na wzajemne powiązania właściwości pamięci i lingwistycznej formy jej reprezentacji. Innymi słowy, pamięć wpływa na język, za pomocą którego jest wyrażana, zaś język jej wyrazu może wpływać na pamięć. Wspomniani autorzy skupiają się na formach lingwistycznych języka, które mogą pełnić rolę niejawnych znaczników kodujących czas zdarzenia. 


\section{ZNACZENIE PROBLEMATYKI}

Każdy, kto zajmuje się problematyką ludzkich wspomnień, stawia (lub powinien stawiać) sobie pytanie, na ile pamięć przeszłości odpowiada rzeczywistości, której jest ona odzwierciedleniem (Stanisławiak 2005). W jaki sposób przeszłość jest konstruowana? Jakie mechanizmy leżą u jego podłożą? Pytania te zdają się naturalne szczególnie w odniesieniu do pamięci. Jak zauważa A. Niedźwieńska (Niedźwieńska 2005), choć pewność co do trafności relacji retrospektywnych może nie mieć wielkiego znaczenia na co dzień (kiedy to zdajemy sobie sprawę z ich subiektywnego charakteru), to jednak w kontekście badawczym (np. podczas wnioskowania na ich podstawie o zaistniałych zmianach lub ich charakterze), terapeutycznym (np. pamięć doznanych krzywd, zdarzeń traumatycznych) lub diagnostycznym (np. w kontekście zeznań świadków) zdaje się mieć znaczenie kluczowe. Nie wiadomo jednak, na ile perspektywa czasowa kształtuje pamięć naszej przeszłości oraz na ile wpływ ten podlega naszej kontroli. Badania umożliwiające udzielenie odpowiedzi na tego typu pytania pozwolą uwzględnić (być może również kontrolować) wpływ perspektywy czasowej na proces konstruowania wspomnień (szczególnie w sytuacjach uzależniania od nich decyzji podejmowania odpowiednich środków działania, np. postępowania terapeutycznego itd.). Nie znaczy to, że będzie można na tej podstawie całkowicie wyzbyć się zniekształceń pamięciowych (które zdają się naturalne i umożliwiają również optymalne funkcjonowanie). Co więcej, pomimo tego, że zagadnienie zniekształceń w pewnych sytuacjach jest kwestią kluczową, to jednak w kontekście perspektywy czasowej wydaje się mieć znaczenie drugorzędne.

Dotychczas psychologowie, mówiąc o perspektywie czasowej, koncentrowali się w głównej mierze na przyszłości, pomijając najczęściej bezpośredni wpływ perspektywy czasowej na pamięć osobistej przeszłości ${ }^{10}$. Z tego względu najważniejszym znaczeniem badań nad możliwym wpływem przyjmowanej perspektywy czasowej na pamięć autobiograficzną jest możliwość pokazania oraz opisania kolejnego i mało jeszcze znanego mechanizmu konstruowania przeszłości (tj. różnych jej odmian niezależnie od tego, jak bardzo są bliskie rzeczywistości). W jaki sposób bliska/odległa przeszłość jest oceniana? Wedle jakich kryteriów? Jak jest opracowywana i konstruowana? Empiryczne określenie wpływu perspektywy czasowej na sposób przedstawiania sobie przeszłości stanowić może próbę udzielenia odpowiedzi na tego typu pytania. Znaczenie tego typu badań ma więc charakter zarówno teoretyczny (pytanie o poznawcze, pozapamięciowe mechanizmy konstruowania przeszłości i, w mniejszym stopniu, źródła zniekształceń pamięci zdarzeń), jak również praktyczny (możliwe ich konsekwencje dla terapii, pomocy psychologicznej itd.). Gdyby okazało się, iż charakter opisywanej przeszłości (bliska vs. odległa) sam przez się wpływa na to, jak jest przez nas reprezentowana i pamiętana (tj. oceniana, na jakie jej elementy zwraca się w głównej mierze uwagę itd.), znaczyć by to mogło, iż poza pamięciowymi procesami przywoływania wspomnień z przeszłości istnieją również procesy o charakterze pozapamięciowym (a więc niezależne od treści i rodzaju przywoływanych wspomnień). Jak się wydaje, jest to kwestia najbliższej przyszłości.

10 Choć i w tym zakresie zdumiewać może niewielka liczba prac poświęconych kwestii czasu w analizie, na przykład, procesów motywacyjnych (Maruszewski, Doliński, Łukaszewski i Marszał-Wiśniewska 2008). 


\section{BIBLIOGRAFIA}

Alexander, David L., John G. Lynch, JR. i Qing Wang. 2008. As time goes by: do cold feet follow warm intentions for really new versus incrementally new products?, „Journal of Marketing Research" 45: 307-319.

Baddeley, Alan D. 1992. What is autobiographical memory?, w: Martin A. Conway, David C. Rubin, Hans Spinnler i Willem A. Wagenaar (red.), Theoretical perspectives on autobiographical memory, Dordrecht: Kluver Academic, s. 13-29.

Bajcar, Beata. 2003. Psychologiczne modele temporalności, w: Zbigniew Piskorz i Tomasz Zaleśkiewicz (red.), Psychologia umystu, Gdańsk: Gdańskie Wydawnictwo Psychologiczne, s. 82-95.

Burt, Christopher D.B. i Simon Kemp. 2003. Themes, events and episodes in autobiographical memory, „Memory and Cognition” 2: 317-325.

Conway, Martin A. 1995. Autobiographical knowledge and autobiographical memories, w: David C. Rubin (red.), Remembering our past. Studies in autobiographical memory, Cambridge: Cambridge University Press, s. 67-93.

Conway, Martin A. i Christopher W. Pleydell-Pearce. 2000. The construction of autobiographical memories in the self-memory system, „Psychological Review” 2: 261-288.

Davison, Ian M. i Aidan Feeney. 2008. Regret as autobiographical memory, „Cognitive Psychology" 57: 385-403.

Draaisma, Douwe. 2006. Dlaczego życie ptynie szybciej, gdy się starzejemy, Warszawa: Państwowy Instytut Wydawniczy.

Falkowski, Andrzej, Tomasz Maruszewski i Edward Nęcka. 2008. Procesy poznawcze: pamięć i uczenie się, w: Jan Strelau i Dariusz Doliński (red.), Psychologia. Podręcznik akademicki, t. 2, Gdańsk: Gdańskie Wydawnictwo Psychologiczne, s. 418-445.

Friedman, William J. 1993. Memory for the time of past events, „Psychological Bulletin” $1: 44-66$.

Friedman, William J. 2004. Time in autobiographical memory, „Social Cognition” 5: 591-605.

Friedman, William J. 2005. Developmental and cognitive perspectives on human's sense of the times of past and future events, „Learning and Motivation” 36:145-158.

Klinger, Eric. 1994. On living tomorrow today: the quality of inner life as a function of goal expectations, w: Zbigniew Zalewski (red.), Psychology of future orientation, Lublin: Towarzystwo Naukowe KUL, s. 97-106.

Kulesza, Wojciech. 2008. A co ja robię tu? Teoria poziomu identyfikacji działania dwadzieścia lat później, „Psychologia Społeczna” 3:197-209.

Lens, Willy i Marie Anne Moreas. 1994. Future time perspective: an individual and a societal approach, w: Zbigniew Zalewski (red.), Psychology of future orientation, Lublin: Towarzystwo Naukowe KUL, s. 23-38.

Liberman, Nira i Yaacov Trope. 1998. The role of feasibility and desirability considerations in near and distant future decisions: a test of temporal construal theory, ,Journal of Personality and Social Psychology" 1: 5-18.

Liberman, Nira, Michael D. Sagristano i Yaacov Trope. 2002. The effect of temporal distance on level of mental construal, „Journal of Experimental Social Psychology” 38: 523-534. 
Liberman, Nira, Yaacov Trope i Cheryl Wakslak. 2007. Construal level theory and consumer behavior, „Journal of Consumer Psychology” 2: 113-117.

Loftus, Elizabeth F. 1975. Leading questions and the eyewitness report, „Cognitive Psychology" 7: 560-572.

Łukaszewski, Wiesław. 2003. Wielkie pytania psychologii, Gdańsk: Gdańskie Wydawnictwo Psychologiczne.

Maruszewski, Tomasz. 2001. Psychologia poznania, Gdańsk: Gdańskie Wydawnictwo Psychologiczne.

Maruszewski, Tomasz. 2005. Pamięć autobiograficzna, Gdańsk: Gdańskie Wydawnictwo Psychologiczne.

Maruszewski, Tomasz, Dariusz Doliński, Wiesław Łukaszewski i Magdalena Marszał-Wiśniewska. 2008. Emocje i motywacje: typy motywacji, w: Jan Strelau i Dariusz Doliński (red.), Psychologia. Podręcznik akademicki, t. 1, Gdańsk: Gdańskie Wydawnictwo Psychologiczne, s. 612-630.

McClelland, James L., Bruce L. McNaughton i Randall C. O'Reilly. 1995. Why there are complementary learning systems in the hippocampus and neocortex: insights from the successes and failures of connectionist models of learning and memory, „Psychological Review" 3: 419-457.

Mead, George H. 1932. The philosophy of the present, London: The Open Court Company.

Mitchell, Terence R., Leigh Thompson, Erika Peterson i Randy Cronk. 1997. Temporal adjustments in the evaluation of events: the “Rosy view”, „Journal of Experimental Social Psychology" 33: 421-448.

Nęcka, Edward, Jarosław Orzechowski i Błażej Szymura. 2007. Psychologia poznawcza, Warszawa: Academica Wydawnictwo SWPS, Wydawnictwo Naukowe PWN.

Niedźwieńska, Agnieszka. 2000. Pamięć autobiograficzna, w: Anna Gałdowa (red.), Tożsamość człowieka, Kraków: Wydawnictwo Uniwersytetu Jagiellońskiego, s. 111-126.

Niedźwieńska, Agnieszka. 2004. Poznawcze mechanizmy zniekształceń w pamięci zdarzeń, Kraków: Wydawnictwo Uniwersytetu Jagiellońskiego.

Niedźwieńska, Agnieszka. 2005. Jak pamiętamy siebie z przeszłości? Konsekwencje dynamiki wspomnień dla badania zmiany osobowości, w: Agnieszka Niedźwieńska (red.), Zmiana osobowości. Wybrane zagadnienia, Kraków: Wydawnictwo Uniwersytetu Jagiellońskiego, s. 25-37.

Nosal, Czesław. 2006. Czas w umyśle: psychologiczne modele temporalności, w: Wioletta Dziarnowska i Andrzej Klawiter (red.), Mózg i jego umysty. Studia z kognitywistyki i filozofii umystu, Poznań: Zysk i S-ka, s. 9-26.

Nosal, Czesław. 2007. Psychologia doświadczania czasu. Struktura temporalności człowieka, w: Maria Kielar-Turska (red.), Żyć wspólnie: odkrywać innego, przeciwdziałać zniewoleniu, realizować cele, Kraków: Oficyna Wydawnicza „Impuls”, s. 111-130.

Nussbaum, Shiri, Yaacov Trope i Nira Liberman. 2003. Creeping dispositionism: the temporal dynamics of behavior prediction, „Journal of Personality and Social Psychology” 3: 485-497.

Piolino, Pascale, Beatrice Desgranges, Karim Benali i Francis Eustache. 2002. Episodic and semantic remote autobiographical memory in ageing, „Memory” 4: 239-257.

Ross, Michael. 1989. Relation of implicit theories to the construction of personal histories, „Psychological Review” 2: 341-357. 
Savolainen, Reijo. 2006. Time as a context of information seeking, „Library \& Information Science Research" 28: 110-127.

Semin, Gun R. i Eliot R. Smith. 1999. Revisiting the past and back to the future: memory systems and the linguistic representation of social events, „Journal of Personality and Social Psychology" 6: 877-892.

Skowronski, John J. 2007. Temporal knowledge and autobiographical memory: an evolutionary perspective, w: Robin Dunbar i Louise Barrett (red.), Oxford handbook of evolutionary psychology, Oxford: Oxford University Press, s. 1-36.

Stanisławiak, Ewa. 2005. Konstruowanie wspomnień, „Przegląd Psychologiczny” 3: 243-259.

Stawiska, Anna M. 2004. Wyznaczniki dokładności przechowywania informacji w pamięci autobiograficznej, „Studia Psychologiczne” 2: 81-91.

Trope, Yaakov i Nira Liberman. 2000. Temporal construal and time-dependent changes in preference, ,Journal of Personality and Social Psychology” 6: 876-889.

Trope, Yaakov i Nira Liberman. 2003. Temporal Construal, „Psychological Review” 3: 403-421.

Trope, Yaakov, Nira Liberman i Cheryl Wakslak. 2007. Construal levels and psychological distance: effects on representation, prediction, evaluation, and behavior, „Journal of Consumer Psychology" 2: 83-95.

Tulving, Endel. 1972. Episodic and semantic memory, w: Endel Tulving i Wayne Donaldson (red.), Organization of memory, New York: Academic Press, s. 381-403.

Tulving, Endel. 1984. Précis of elements of episodic memory, „Behavioral and Brain Sciences” 7: $223-268$.

Tulving, Endel. 1985. How many memory systems are there?, „American Psychologist” 4: 385-398.

Tulving, Endel. 2002. Episodic memory: from mind to brain, „Annual Review of Psychology” 1: $1-25$.

Vallacher, Robin R. i Daniel M. Wegner. 1987. What do people think they're doing? Action identification and human behavior, „Psychological Review” 1: 3-15.

Żegleń, Urszula. 2005. System poznawczy jako system reprezentacyjny, „Filozofia Nauki” 4: $37-57$.

Żegleń, Urszula M. 2010. O naturze, rodzajach i sposobie istnienia reprezentacji umysłowych, „Analiza i Egzystencja” 11: 155-185.

TIME PERSPECTIVE AND THINKING ABOUT THE FUTURE AND THE PAST IN THE CONTEXT OF CONSTRUAL LEVEL THEORY

Paper presents Construal Level Theory (CLT, Liberman \& Trope, 1998; Trope \& Liberman, 2003), which proposes that temporal perspective affects people's thinking about future events. Smaller temporal distance effects in more frequent representations of events in terms of concrete details. The greater temporal distance events are represented at a more abstract and general level. There are presented empirical findings suggesting that TCT can also pertain to episodic memory. Further importance, theoretical and empirical implications of Construal Level Theory are discussed. The author also raises questions and challenges for future research.

Key words: construal level theory, mental time travel, episodic memory, temporal perspective 